\title{
THE ROLE OF THE ACCOUNTING IN THE SUSTAINABLE DEVELOPMENT: THE CASE OF SERBIA
}

\author{
Goranka Knežević ${ }^{1}$ Jasmina Gržinić ${ }^{2}$, Predrag Vukadinović ${ }^{1}$ \\ ${ }^{1}$ Faculty of Business in Belgrade, Singidunum University, Belgrade, Serbia \\ ${ }^{2}$ University Juraj Dobrila in Pula, Pula, Croatia
}

\begin{abstract}
:
This paper analyzes the neccessity for establishing the accounting information system that addresses the needs of stakeholders in order to asses the sustainabillity of the resources and results of the specific company. Governments of EU Member States has to fulfil "environmental" obligations and they have to motivate companies to report on their environmental issues in relevant and fair manner. In that sense, Serbia as a candidate and the country in the process of EU integrations needs to put an emphasis on these issues in correlation with the accounting. In this paper we analyzed the concept of sustainable development with its relations with accounting, specifically the concept of capital maintenance, eco efficiency indicators and how they can be derived from the accounting system as well as the practice of reporting on environmental issues by Serbian companies.
\end{abstract}

\section{INTRODUCTION}

Sustainable development is one of the most important issues in the world economic forums today, and integral part of many research conducted in the 20-th and 21-st century. We strongly believe that the next generation would enjoy more material goods and would live better than the current generation. Thus, huge part of the responsibility lays down on economic sector, our wealth depends on the business methods used in the economic sector. But the world economic crisis in 2008 shows that profit could not be the only goal and that is why many of academicians started to challenge this idea.

Ideas of sustainability has been challenged in terms of accounting system as well. Accounting is the only information system developed for the purpose of measuring business results. When business entities started to become environmentally responsible, accounting was tailored to suit the needs of measuring and informing potential and current stakeholders of what the business had done in this area. Currently no accounting or auditing standard was developed in this area, although specific references are made in some of the published standards, such as IAS 37, IAS 38 and IAS 16. Most of these requirements are satisfied by companies usually through presenting the footnotes that relate to environmental issues.

The main hypothesis posed by all of the above presented should be how can we measure business success in the domain of sustainable development and what is the role of accounting in that measurement. It is obvious from the above presented that the same principles and rules from the conventional accounting and measurement could not apply in the area where sustainability has been promoted as the primary issue. This article will try to answer the questions of how can we measure profit focusing on sustainability of resources and what are the accounting rules applied on the measurement of transactions arising from the environmental issues.

This paper is organized as follows: sustainable development and its relations with the accounting, environmental accounting and eco efficiency in Serbia and conclusion and recommendation for the future research.

\section{SUSTAINABLE DEVELOPMENT AND ITS RELATIONS WITH THE ACCOUNTING - GENERAL TRENDS}

The EU legislator has expressed unquestionable support to adoption and implementation of the concept of sustainable development in the area of its jurisdiction. In European Union environmental policy belongs to shared competencies, meaning that EU institutions and governments of EU member states share responsibility in terms of its implementation. The goal of this policy is not only protection of environment in the current condition, but - after entry of The Lisbon Treaty on EU into force in 2009 - an obligation of its quality improvement for the purpose of sustainable development establishment. Despite the fact that sustainability is supported by various institutions and initiatives, it is still very sophisticated concept.

Bruntland Commission report in 1987 that states that sustainability is the „development that meet the needs of present without compromising the ability of future generations to meet their own needs" (Bruntland Commision Report, 1987. p.15). Yet in the end, sustainable development is not a fixed state of harmony, but rather a process of change in which the exploitation of resources, the direction of investments, the orientation of technological development, and institutional change are made consistent with future as well as present needs (Bruntland Commission Report, 1987, p.15).

Many organizations such as World Bank, International Monetary Fund and World Trade Organization supported the idea of sustainable economic growth. The World Bank (2010), which has affirmed a commitment to "sustainable globalization" that "enhances growth with care for the environment"; the International Monetary Fund (IMF, 2010), with a commitment to "sustainable economic growth"; as well as the World Trade Organization (WTO, 2010) which endeavors to contribute to sustainable development through the pursuit of open borders and the removals of barriers to trade.

In Serbia, the concept of sustainable development has been enforced by the Law on Environment protection (Official Ga- 
zette of the Republic of Serbia, 135/2004, 36/2009, 36/2009 $72 / 2009$, article 9 ) where the principle of sustainable development of the Republic of Serbia was mentioned. This principle is applied through other articles such as article 75 where Government has an obligation to establish the National register of sources of environmental pollution, and all polluters are forced to pay fines for the damage that they cause to the environment (article 85). In the same article the Law establishes the criteria to be used in order to calculate the adequate fine. The fines collected by the Government are included as revenues in the budget of the Republic of Serbia (60\%) and the rest is included as revenue of the municipality where polluter has done the damage. The Law requires that all projects should be evaluated from the environment perspective (article 36 ) which directly promotes the sustainability principle in the business activities. In the article 45 of the Law, polluters should apply the EMAS (Environmental Management Accounting System) and should be verified by the authorized institution).

According to all of the above mentioned, sustainability requires intergenerational aspect of economic growth and sustainable production and consumption of resources. So, the main question is how can business respond to the sustainable development, because it seems that the economic sustainability is of a primary importance, not only because businesses satisfy the needs of current generation, but they jeopardize the environment and prevent future generations to consume the resources and have more wealth. Sustainability has two elements: one of which concerns the environmental issues (eco efficiency) and one of which deals with social elements (eco justice) (Rob Gray, David Collison and Jan Bebbington, 1997). In this case it seems that two types of accounting are required, such as: social responsibility accounting that cope with the issue of eco justice and environmental accounting that deals with the issue of eco efficiency. In the next section we are going to deal with the environmental accounting in the area of eco efficiency.

\section{ENVIRONMENTAL ACCOUNTING AND ECO EFFICIENCY IN SERBIA}

Many organizations at the EU and global level tried to answer the question of how to treat environmental issues in accordance with the sustainable development. The EU Fifth Action Program on the Environment, (Towards Sustainability) has signaled its desire for accounting to redefine its concepts, rules, conventions and methods so that the full cost of consuming and using environmental resources are calculated It is believed that this will lead to changed use of resources and hence will assist the pursuit of sustainability. The United Nations Conference on Trade and Development has instigated a range of research projects intended to explore how accounting might contribute to a move towards sustainability. The most recent of these are summarized in International and Accounting Reporting Issues: 1995 Review. Despite all of these considerable efforts, Serbian accountants are still at the edge of these issues and our environmental consciousness is very low. This is due to many reasons.

Environmental reporting by Serbian companies is presented in annual reports as an official form of transmitting accounting information, or in supplemental reports. Annual reports of Serbian companies required to follow IFRS/IAS and they consist of Balance Sheet, Income Statement, Cash flow Statement, Statement of Changes in Equity and Statement of Other comprehensive income. All these reports are prepared in accordance with the Rulebook on the content of items comprising Balance Sheet, Income Statement and Cash flow Statement (Official Gazette of the Republic of Ser- bia No.53/2004, 11/2005, 51/2005, 24/14). It means that Serbian companies use standardized financial statements. Law on Accounting requires that large companies should make their financial statement visible to users and all of the companies use the web site as a reporting medium, because of its global visibility and good quality of presentation of the reports. Reports are also submitted to the Serbian Business Registers Agency that makes them visible on its web site. Although, Law does not require which medium to use to make the reports visible. In regular companies do not present any environmental information in the annual report. That is why this report is supplemented by additional reports to show environmental information. There is no law governing these issues and reports are prepared on a voluntary basis. In Serbia these reports are required in the case when company is included in some general projects for the environmental preservation (for example projects by UN Compact Group). Company is then required to improve its environmental information transmission as a part of the results of the project. In this specific case, additional report on environment is presented in electronic form, especially through company's web site. Serbian Agency for Environmental Protection published the National register of polluter sources in Serbia which contains name of the company or subsidiary that damages the environment. All of these companies, according to the Law have been required to submit annual reports on emission to the air and water, waste management, special movement of waste streams and etc (http://www.sepa.gov.rs/download/NRIZ_podaci/SpisakPRTR.pdf, accessed on October 2014). Although this report on emissions is additional report which content is prescribed by the Agency, and it contains information regarding material flows in production or rendering services that damage the environment. So, this type of information is non financial by its nature, so there is no need for the accountants to prepare this report. All of these reports are prepared using the electronic system on the Agency web site and they have required structure and content for each polluter (basic information regarding company and detailed information regarding emissions in air and water, deposited waste etc.).

\subsection{Hypothesis of a research}

Based on the above presented we developed the following working hypothesis for the research:

H1: The practice of reporting on environment by Serbian biggest polluters is quite divergent and no standardized criteria are followed.

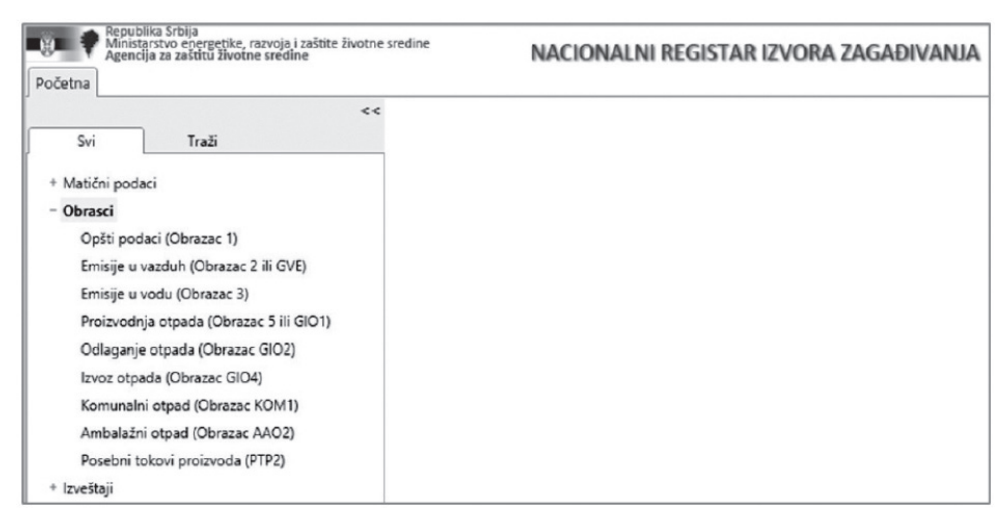

Picture 1. Electronic system of preparing supplemental reports on emissions and waste management

[Source: Agency for the Environmental Protection, Republic of Serbia, web site: http://80.93.233.116/UserReg/Uputstvo.pdf (accessed on October 2014)] 


\begin{tabular}{|c|c|c|c|c|c|c|c|}
\hline Company /Criteria & $\begin{array}{c}\text { Environmental info } \\
\text { in annual reports and } \\
\text { footnotes }\end{array}$ & $\begin{array}{l}\text { Environmental } \\
\text { information in } \\
\text { Business report }\end{array}$ & $\begin{array}{l}\text { Environmental } \\
\text { report }\end{array}$ & $\begin{array}{l}\text { Web site section } \\
\text { on environment }\end{array}$ & $\begin{array}{c}\text { News regarding } \\
\text { environment }\end{array}$ & $\begin{array}{c}\text { EMAS } \\
\text { certificate }\end{array}$ & $\begin{array}{c}\text { ISO } \\
\text { certificate }\end{array}$ \\
\hline Messer Tehnogas a.d. & No & $\begin{array}{l}\text { Yes, for the year } \\
2013\end{array}$ & No & $\begin{array}{l}\text { Yes, Corporate so- } \\
\text { cial responsibility }\end{array}$ & Yes & Yes & Yes \\
\hline HIP Petrohemija Pančevo & No & No & Yes & $\begin{array}{l}\text { Yes, Ecological } \\
\text { responsibility }\end{array}$ & Yes & Yes & Yes \\
\hline Holcim, d.o.o & No & No & Yes & $\begin{array}{l}\text { Yes, Corporate } \\
\text { responsibility }\end{array}$ & Yes & No & Yes \\
\hline Carnex, a.d. & No & No & No & Yes, Ecology & Yes & No & Yes \\
\hline Zdravlje Actavis a.d. & No & $\begin{array}{l}\text { Yes, in } 2010 \text { (in- } \\
\text { vestment section) }\end{array}$ & No & Yes & Yes & No & Yes \\
\hline NIS, Naftna industrija Srbije & No & Yes & Yes & $\begin{array}{c}\text { Yes, Sustainable } \\
\text { development }\end{array}$ & Yes & Yes & Yes \\
\hline Kolubara Lazarevac & No & No & Yes, 2011 & Yes, Environment & Yes & No & Yes \\
\hline Apatinska pivara, doo & No & No & No & $\begin{array}{l}\text { Yes, corporate } \\
\text { responsibility }\end{array}$ & Yes & No & No \\
\hline Perutnina Ptuj Topiko & No & No & No & Yes & No & No & No \\
\hline Alfa Plam & No & Yes & No & No & No & No & Yes \\
\hline Total & 0 & 4 & 4 & 9 & 8 & 3 & 8 \\
\hline
\end{tabular}

Table 1: Results of the research regarding presentation of environmental information in annual reports, web sites and additional reports of Serbian polluters

[Source: Author's own calculation]

H2: Companies prefer to publish environmental information in additional reports such as business report and web site or special reports on environment than in regular financial statements. In that case they avoid auditors opinion about the numbers.

H3: Companies in the news section report only positive news regarding their environmental impact.

In the next section we created the sample and investigated whether these hypothesis hold true or not in Serbian environment.

\subsection{Sample structure and methodology}

The research is conducted on a sample of 10 Serbian companies determined to be the polluters and registered at the National register of polluters at the Agency for the Environment protection as http://www.sepa.gov.rs/download/NRIZ_podaci/ SpisakPRTR.pdf, accessed on October 2014). List consists of approximately 80 companies whose production or factory causes damage to the environment by emissions of gas or by disposing of waste.

From that register we took on a haphazard basis 10 companies from different sectors, namely, Messer Tehnogas, a.d., HIP Petrohemija Pancevo, Holcim, Carnex, Zdravlje Actavis, NIS, Kolubara Lazarevac, Apatinska pivara, Perutnina Ptuj Topiko, Alfa Plam in order to see the content and the existence of their environmental information in the published reports and supplemental reports or news on the web site. In order to test the hypothesis we applied the content analysis (Unerman, 2000) as a research method which best suits the needs of this research.

\subsection{Research results and analysis}

In this section research results are presented. In order to better understand the research findings we prepare the following table:

In the above presented table 1 we can conclude that the majority of the companies have web site section devoted to the environment or social responsibility issues (9 out of 10), than they present environmental news using web site (9 out of 10) and 8 of these companies have ISO certificate. Only 4 companies present Environmental report or they have one paragraph of Business report (management report) publishing their investment in the environment.

In the Business Report of Messer Tehnogas for the year 2013 (http://www.messer.rs/documents/Izvestaji2013/Konsolidovani2013.pdf, accessed on October 2014) one section is devoted to the information regarding investments in the environment such as the installation of the piezometer in Rakovica and Kraljevo in order to monitor the pressure of groundwater, then it published that certain equipment is purchased such as new boilers that are more efficient in energy transmission than old ones. No numbers in correlation with all of these investments are mentioned in the report. Messer did not publish environmental or corporate responsibility report. Corporate web site presents 7 news regarding corporate social responsibility, and all of these news is by nature positive.

From the above mentioned, we can conclude that the accounting regulative framework in Serbia for environmental reporting is at a very low level in a sense that it does not facilitates the transmission of that kind of information by Serbian companies. From one research done on the Serbian sample of Belex 15 companies, the results showed that 6 companies do not have any report on environment, 3 companies present this information as a part of Report on Business, 2 of them publishes short news about environment on the web sites (Pavlovic, Muminovic, Cvijanovic, 2012). Some other researchers (Knezevic, Stanisic, Stanisic, 2008) use case study methods showing that the biggest polluters in Serbia in that period (namely Petrohemija Pancevo, Holcim i Elektroprivreda Srbije) did not present environmental reports even if some of them paid heavy fines for the damage they cause to the environment.

All over all, the hypothesis that we presented at the beginning of this research showed that the practice of reporting on the environmental issues has been divergent and non- standardized. Companies prefer to publish positive information regard- 
ing the environment and to present information regarding investments in the environmental projects in the business report.

\section{CONCLUSION}

Environmental accounting gains importance at the end of the 20th century when awareness about sustainable development and growth has become the primary goal of all business entities. Accounting as a measurement system has its role in the development of measures to evaluate the sustainable growth of a company and to promote sustainability as a goal of accounting. Unfortunately, Serbia has been at the edge of these processes because stakeholders still believe that profit is the primary motive for business activities. That is why companies do not put much of the interest into publishing envieironmental data and reports.

\section{REFERENCES}

[1] Bruce LH, Robert NS, Vietor RHK (2005). Environmental Protection and the Social Responsibility of Firms: Perspectives from Law, Economics and Business, Resources for the Future. Washington DC

[2] Business Principles to Environmental Management, Harvard Business School Press.

[3] Certified Accountants Educational Trust (2001). Environmental, Social and Sustainability reporting on the World Wide Web: A guide to best practice. London.

[4] Consolidated versions of the Treaty on European Union and the Treaty on the Functioning of the European Union. OJ. of the EU2008/115/01http://www.consilium.europa. eu/showPage.aspx?id=1296\&lang=en (accession date: Feb., 2014)

[5] Global Reporting Initiative Guidelines from the web site: https://www.globalreporting.org/reporting/g4/Pages/default. aspx (accessed on Feb, 2014)

[6] Gray,R; Collins, D., Bebington J., Struggling with the praxis of social accounting: Stakeholders, accountability, audits and procedures", Accounting, Auditing \& Accountability Journal, Vol. 10 Iss: 3, pp. 325-364, 1997

[7] Holcim Srbija doo, Izvestaj o održivom razvoju Holcim Srbija doo za 2011.godinu, from the web site: http:/holcim.rs/ fileadmin/templates/CS (accesed on Feb, 2014)
[8] IFRS, Conceptual framework, Draft discussion paper, Capital maintenance, London,2013 (www.ifrs.org/Meetings/ MeetingDocs/.../05H-Conceptual-Framework.pd, accessed on October 2014)

[9] IMF, A Multi-Donor Trust Fund for Capacity Building Technical Assistance in Managing Natural Resource Wealth, 2010. http://www.imf.org/external/np/otm/2010/110110.pdf, accessed on October 2014)

[10] Kostić M (2009). Eco-label as a form of information on products. Business Law and European Integrations. Law and Economy 5-8: pp. 89-92 (in original: Eko-oznaka kao vid informacije o proizvodima. Pravo i privreda 5-8: str. 89-92)

[11] Kostić M, Gasmi G (2010). The Lisbon Treaty on EU and Corporate Responsibility and Environmental Responsibility. Law and Economy 7-9: 350-360 (in original: Lisabonski ugovor o EU i korporativna društvena i ekološka odgovornost. Pravo i privreda 7-9: pp. 350-360)

[12] Law on Environment protection (Official Gazette of the Republic of Serbia, 135/2004, 36/2009, 36/2009 72/2009

[13] Pavlovic V. Muminovic S., Cvijanovic J.Izveštavanje o održivom razvoju blue chip kompanija u Srbiji,

[14] Pavlović, V., Muminović, S., Cvijanović, J., Korporativno izveštavanje o održivom razvoju "blue chip" kompanija u Srbiji,International Conference on Social and Technological Development (STED), "Contemporary Concepts and Challenges of Social and Technological Development in the Globalization Era", University for Business Engineering and Management, Banja Luka, 28-29 septembar 2012, pp. 589-600. UDC 658.1(CD izdanje)

[15] Rulebook on the content of items comprising Balance Sheet, Income Statement and Cash flow Statement, Official Gazette of the Republic of Serbia No.53/2004, 11/2005, 51/2005.

[16] Unerman J. (2000) Reflections on quantification in corporate social reporting content analysis, Accounting, Auditing and Accountability Journal, vol. 13, No. 5, pp. 667-681

[17] United Nations, Bruntland Commission Report 1987, New York, 1987.(http://conspect.nl/pdf/Our_Common_FutureBrundtland_Report_1987.pdf, accessed on October 2014)

\title{
ULOGA RAČUNOVODSTVA ZAŠTITE ŽIVOTNE SREDINE U ODRŽIVOM RAZVOJU: PRIMER REPUBLIKE SRBIJE
}

\author{
Goranka Knežević1 Jasmina Gržinić ${ }^{2}$, Predrag Vukadinović ${ }^{3}$ \\ ${ }^{1}$ Poslovni fakultet u Beogradu, Univerzitet Singidunum, Danijelova 32, Beograd, Srbija, gknezevic@singidunum.ac.rs \\ ${ }^{2}$ Sveučilište Juraj Dobrila u Puli, Zagrebačka ulica 30, Pula, Hrvatska, jloncar@unipu.hr \\ ${ }^{3}$ Poslovni fakultet u Beogradu, Univerzitet Singidunum, Danijelova 32, Beograd, Srbija, pvukadinovic@singidunum.ac.rs
}

\begin{abstract}
Apstrakt:
$\mathrm{U}$ ovom radu analizira se potreba da računovodstveni sistem odgovori zahtevima stejkholdera $\mathrm{u}$ domenu održivosti upotrebe resursa i poslovnih rezultata koji su kompanije ostvarile. Vlade zemalja članica Evropske unije moraju da zadovolje kriterijume zaštite životne sredine, što i čine vršeći pritisak na kompanije u tim zemljama da izveštavaju o zaštiti životne sredine na relevantan i pouzdan način. U tom smislu, i Srbija kao kandidat za članstvo u EU i u delu integracionih procesa sa EU, mora imati kao jedan od prioriteta i razvoj računovodstva u kontekstu održivog razvoja zemlje u celini. U ovom radu analizirali smo koncept održivog razvoja i njegov odnos sa računovodstvom, posebno u domenu održanja kapitala kompanije, indikatore ekonomske efikasnosti i kako se oni mogu derivirati iz računovodstvenih informacija, kao i praksu izveštavanja srpskih kompanija u delu zaštite životne sredine i održivog razvoja.
\end{abstract}

\section{Ključne reči:}

računovodstvo zaštite životne sredine,

održivi razvoj,

koncepti održanja kapitala,

indikatori ekonomske efikasnosti. 